\title{
First record of Andrena chrysopus Perez, 1903 (Hymenoptera: Apiformes: Andrenidae) in Poland
}

\author{
Lucyna TWERD \\ Department of Environmental Biology, Kazimierz Wielki University, Ossolińskich 12, 85-093 Bydgoszcz, Poland; \\ e-mail:l.twerd@ukw.edu.pl
}

\begin{abstract}
The paper presents data about the first record of Andrena chrysopus Perez, 1903 in Bydgoszcz, Poland (the Wielkopolsko-Kujawska Lowland). It is an oligolectic species, closely linked to plants in the genus Asparagus sp. During 2018-2019 (May-June), 54 speciemens of the species were collected at 9 sites during the flowering period of the host plant. The bees were recorded in dry and well sunlit biotopes on the outskirts of the city and in residential-industrial districts. The observations confirmed the occurrence of stable populations of A. chrysopus. However, increasing urbanisation and succession may threaten the presence of the species in the genus Asparagus sp., and thus A. chrysopus, which strongly relies on these species' food sources.
\end{abstract}

Key words: wild bees, synurbization, new species, Asparagus officinalis

\section{INTRODUCTION}

Urbanization is one of the main anthropogenic processes contributing to local changes in the environment. Intensification of human activities within urban areas increases habitat changes and is the leading cause of species extinction and reduction in biodiversity (Hostetler \&McIntyre 2001, McKinney 2002, 2008, Shochat et al. 2010). Although urbanization processes threaten many animal species, there are many examples of cities also playing a positive role in maintaining biodiversity (Fetridge et al. 2008, Fortel et al. 2014, Banaszak-Cibicka et al. 2018). According to some researchers (Lundholm \& Richardson 2010, Menke et al. 2011, Holzer 2014, Eckert et al. 2017, Twerd \& Banaszak-Cibicka 2019), cities also provide shelter for many species, including rare and endangered ones.

Cities are increasingly seen as important habitats for wild bees (Buchholz et al. 2020). Properly designed and managed urban green spaces are often an attractive habitat for many species, and the richness and abundance of bees in these areas can be comparable to natural areasi (Banaszak-Cibicka et al. 2018). An important and complementary role in shaping the diversity of Apiformes is played by both managed green spaces and urban wastelands, including open spaces (Lerman and Milam 2016, Twerd et al. 2021a,b) and urban forests (Donnelly and Marzluff 2004, Kowarik and Körner 2005, Dylewski et al. 2019).

The Holarctic subgenus Euandrena (genus Andrena) was described by Hedicke in 1933. Currently, in the Palearctic region, the subgenus is represented by 54 species, and in the Nearctic region by 21 species (Ascher \& Pickering 2011, Huan-li \& Tadauchi 2012). Thirty one species have been detected in Europe, including 7 in Poland (Banaszak 2000). The geographical range of Holarctic species A. chrysopus in Europe covers Slovakia, the Czech Republic, Germany, Romania, Hungary, Austria, Switzerland, southern France, northern Italy, Greece, Ukraine, and the north-western part of Russia. The species is registered locally, within a divided range (Rasmont et al. 2013). 


\section{METHODS}

The Andrena chrysopus were caught from May to June, along a single transect with a length of $100 \mathrm{~m}$ and a width of $1 \mathrm{~m}$. During the passage, all bees were netted from Asparagus officinalis for one hour. The insects were collected when the weather was favorable for bee activity, i.e., with no or very little wind ( $<3$ on the Beaufort scale), when the visibility of a cloudless sky was at least $70 \%$, and at temperatures exceeding $16^{\circ} \mathrm{C}$ (Krauss et al. 2009). Temperature, cloudy and wind data were extracted from the ICM UW weather data (Interdisciplinary Centre for Mathematical and Computational Modelling, University of Warsaw).

The specimens are deposited in the author's collection. Research was conducted after obtaining oral consent from the owners and managers of the land and in accordance with applicable law.

\section{RESULTS}

\section{Andrena chrysopus Perez, 1903}

Synonym: Andrena dobrowlanensis Noskiewicz, 1923

Material. In Poland, the species is recorded from the Wielkopolsko-Kujawska Lowland:

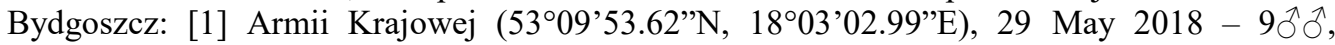

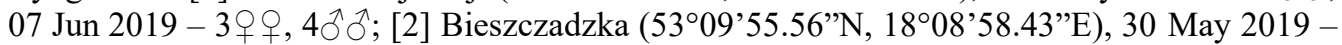

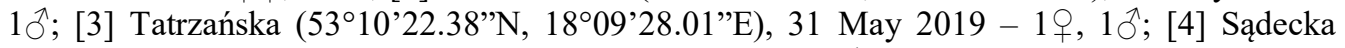

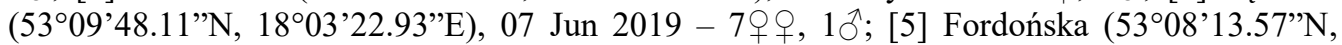

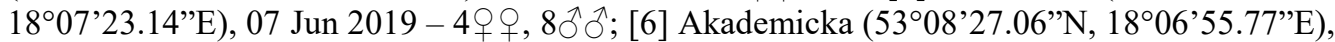

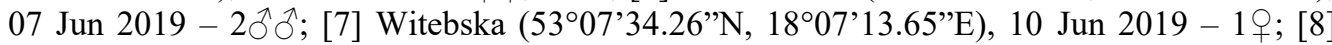

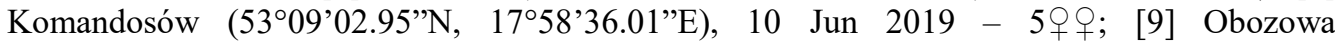

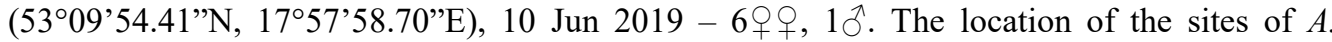
chrysopus in Bydgoszcz is presented in Fig. 1.

Diagnosis. The female can be distinguished from the very similar Andrena symphyti by the following features: facial depressions (foveae) with yellow-brown hairs occupy $1 / 3$ of the distance between the upper edges of the compound eyes and the lateral ocelli (See: Dylewska 2000). Abdominal tergites 5-6 are hairy and mostly rusty yellow or rusty brown. The male can be distinguished from Andrena symphyti by the following features: intensively shiny back of the thorax, the abdominal tergites partly reddish or brownish-red, and penis valvae with a characteristically pointed widening. Distingushing features are listed according to Dylewska (2000).

Description of specimens caught. Female: Body length: 9-10 mm; Structure: Labrum strongly convex, shiny, regularly and clearly punctate, interspaces shiny. Ocelli distanced from the back edge of the head by approx. (up) to 1.5 of the diameter ocellus. Antenna short, reaching the scutellum, third and fourth segments of the antenna equal to the second. Anterior part of the scutum matt, middle and posterior parts punctate and shiny between punctures. Anterior part of the scutellum shiny. Tibia 3 pairs of legs not widened.

Colouration: Black head. Wings yellowish, veins brownish-yellow, stigma brownish-yellow. Hind and middle feet translucent red. Tergites clearly punctate, slightly shagreened, ends reddish (sometimes all tergites red).

Pubescence: Head with short, white hairs (no black hairs). T2-T4 covered with whitishyellow hairs, T5 with light brown hairs. Sternites covered with yellowish-white hairs. Penis valvae with a characteristically pointed widening. 

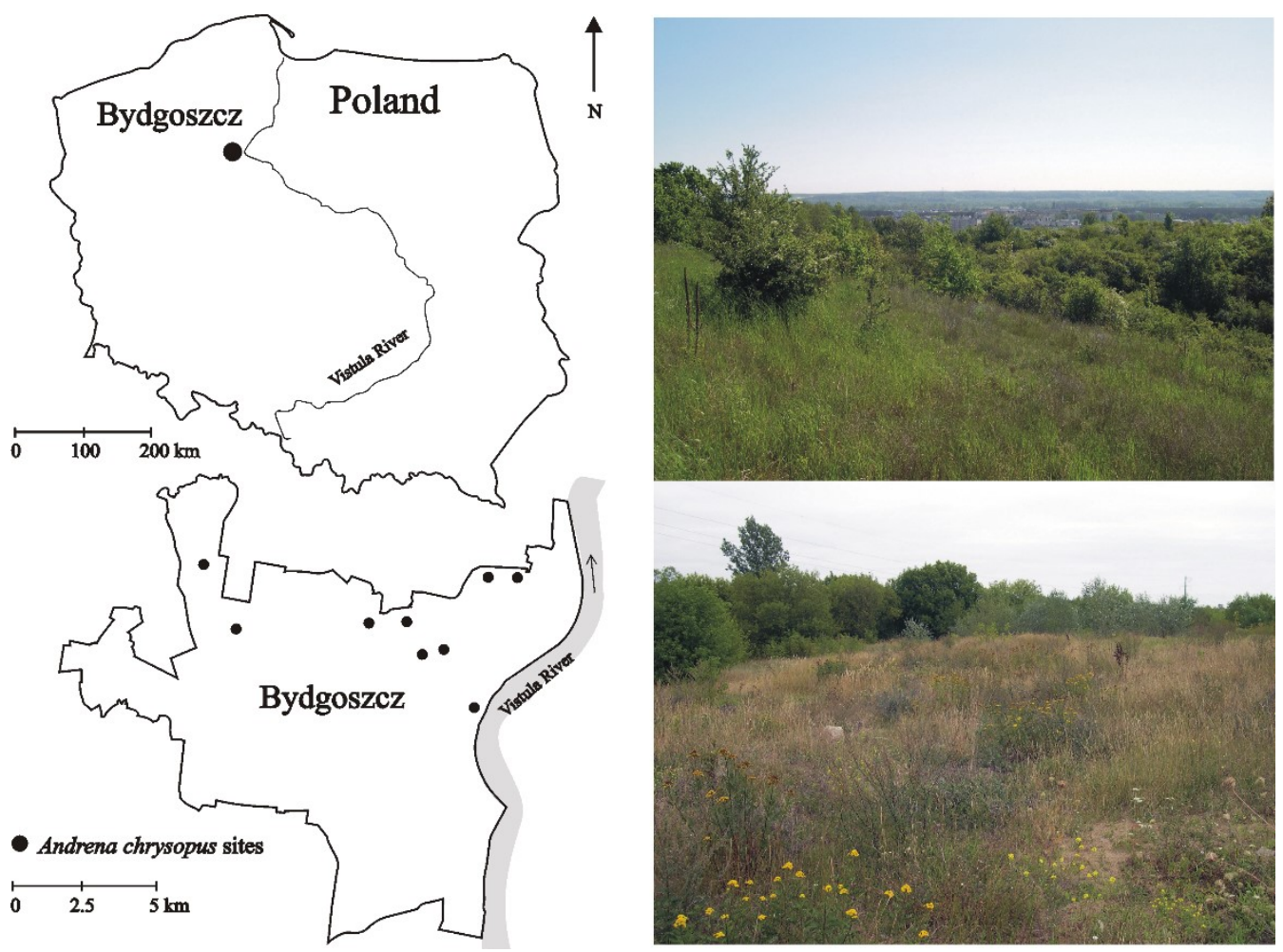

Fig. 1. Andrena chrysopus occurrence sites in Bydgoszcz (Poland).

Male: Body length: 7-9 mm. Body structure and hair similar to females. The colouration is lighter than in females. Penis valvae with a characteristic pointed widening.

Biology and habitat preferences. Biology: univoltine species. It nests singly in the ground; no clusters of nests are made. Ellipsoidal cells are $6.5-14.5 \mathrm{~cm}$ below the ground surface (Radchenko 1980).

Environment: prefers dry and well sunlit biotopes (Fig. 1).

Flying period: from the end of April to June (Osytshnjuk1977, Dylewska 2000).

Trophic associations: The character of trophic connections has not been thoroughly explained. In some areas, the species is considered to be oligolectic, related to Asparagus sp. as its main pollinator, both in cultivation and natural habitats. In the present study, as in Radchenko's (1980) findings, A. chrysopus fed only on Asparagus officinalis, despite having an abundance of food plants at its disposal.

\section{DISCUSSION AND CONCLUSIONS}

The detection of a new species for Poland in Bydgoszcz, Andrena chrysopus Perez, 1903, proves that cities can play an important role as habitats and sites of wild bees.

A. chrysopus is a fairly rare species found locally in southern Europe. Dylewska (2000) indicated that this species might be found in Poland, albeit in the southern part of the country. However, its first record concerns northern Poland. On the other hand, it is not the northernmost site of $A$. chrysopus occurrence in Europe. This species has also been found relatively recently 
in the north-west of the European part of Russia, i.e. in the Moscow and Kirov regions, and thus increased its northern range to $56^{\circ} \mathrm{N}$ (Levchenko 2010, Levchenko \& Yuferev 2015).

Some researchers (Radchenko 1980, Dylewska 2000, Gogala 2004) consider Andrena chrysopus an oligolectic species, i.e. closely related to plants of the genus Asparagus sp. There are three species of asparagus in the Polish flora: Asparagus officinalis L., A. tenuifolius L. and A. acutifolius L., of which only the first species grows wild. Asparagus visited by A. chrysopus is a species characteristic of xerothermic grasslands of the order Festucetalia valesiacae. Hence, it is usually found on dry slopes, roadside areas or in not dense thickets. In Bydgoszcz, sites occupied by this species, and those associated with $A$. chrysopus, were found both in wastelands located on the outskirts of the city and in residential and industrial districts located in its central part. The largest concentrations of $A$. officinalis and numerous populations of $A$. chrysopus were recorded in the upper terrace of the Vistula river. The species analysed was found in nine places in Bydgoszcz, i.e. in most of the sites where its host plant was found. At the same time, research conducted outside Bydgoszcz to date has not led to the discovery of A. chrysopus, despite the frequent occurrence of $A$. officinalis.

In light of the analysis of $A$. chrysopus distribution in Bydgoszcz and the attempt to assess the threats to this species, it can be concluded that at present they mainly result from the risks to the occurrence of Asparagus officinalis. Both urbanisation and plant succession play a negative role in this case. Ukrainian researchers have also reached similar conclusions. According to the Red Book of Ukraine (Akimov 2009), due to the cessation of economic use of grasslands with steppe vegetation, a sharp decline in the population of Asparagus sp. is observed, which poses a significant threat to the presence of $A$. chrysopus in this country.

A similar situation occurs in Bydgoszcz. The location of the city on the Brda River, at its confluence with the Vistula River, leads to great diversification of the topography. A characteristic feature of this area is the existence of a system of vast, flat terraced levels and high plateaus, as well as edge zones of the ice-marginal valley and river valleys covered with degraded xerothermic and psammophilic grasslands. After sheep grazing ceased in this area (approx. 20 years ago), these habitats have been gradually degrading due to the progressive development of slopes and the process of spontaneous succession. This poses a real threat to the continued occurrence of $A$. chrysopus in Bydgoszcz.

\section{ACKNOWLEDGEMENTS}

I wish to thank Prof. dr hab. Józef Banaszak for the verification of Andrena chrysopus identification. I thank the reviewers for their constructive comments which helped to me improve the manuscript.

\section{REFERENCES}

AKIMOV I. A. (ed.) 2009. Červona kniga Ukraïni, svit. Globalkonsalting 600 pp. (in Ukrainian)

ASCHER J., PICKERING J. 2011. Bee Species Guide (Hymenoptera: Apoidea: Anthophila), Available at: https://amnh.discoverlife.org.

BANASZAK J. 2000. A chrcklist of the bee species (Hymenoptera, Apoidea) of Poland, with remarks on their taxonomy and zoogeography: revised version. Fragmenta Faunistica 43(14): 135-193.

BANASZAK J., TWERD L., RATyŃSKA H., BANASZAK-CiBICKA W. \& ZYŚ T. 2018. Andrena florea Fabricius, 1793 (Hymenoptera, Apoidea, Apiformes): a rare bee species in Poland, related to the expansion of the alien plant Bryonia dioica JACQ. (Cucurbitaceae). Polish Journal of Entomology 87(3): 199-215. DOI: 10.2478/pjen-2018-0015

BANASZAK-CIBICKA W., TWERD .L, FLISZKIEWICZ M., GIEJDASZ K. \& LANGOWSKA A. 2018. City parks vs. natural areas - is it possible to preserve a natural level of bee richness and abundance in a city park? Urban Ecosystems 21: 599613. DOI: $10.1007 / \mathrm{s} 11252-018-0756-8$

Buchholz S., GAthof A. K., Grossmann A. J., KowARIK I. \& Fischer L.K. 2020. Wild bees in urban grasslands: urbanisation, functional diversity and species traits. Landscape and Urban Planning 196, 103731. DOI: 10.1016/j.landurbplan.2019.103731 
DONNELly R. \& MARZLUfF J. M. 2004. Importance of reserve size and landscape context to urban bird conservation. Conservation Biology 18 (3), 733-745.

DYlewsKa M. 2000. Pszczołowate - Apidae, Podrodzina: Andreninae. Klucze do oznaczania owadów Polski, 14, Błonkówki - Hymenoptera. 68d. Edition 2. Polskie Towarzystwo Entomologivzne, Toruń, pp. 1-152.

DYLEWSKI L., MAĆKOWIAK L. \& BANASZAK-CIBICKA W. 2019. Are all urban green spaces a favourable habitat for pollinator communities? Bees, butterflies and hoverflies in different urban green areas. Ecological Entomology, 44, 678-689. DOI: 10.1111/een.12744

ECKERT S., MÖLLER M. \& BUCHHOLZ S. 2017. Grasshopper diversity of urban wastelands is primarily boosted by habitat factors. Insect Conservation and Diversity 10 (3): 248-257. DOI: 10.1111/icad.12221

Fetridge E. D., Ascher J. S. \& LANGellotto G. A. 2008. The bee fauna of residential gardens in a suburb of new York City (Hymenoptera: Apoidea). Annals of the Entomological Society of America 101: 1067-1077. DOI: 10.1603/0013-8746-101.6.1067

Fortel L., Henry M., Guilbaud L., Al G., Kuhlmann M., Mouret H., Rollin O. \& Vaissière B. E. 2014. Decreasing abundance, increasing diversity and changing structure of the wild bee community (Hymenoptera: Anthophila) along an urbanization gradient. PLoS One 9(8): e104679. DOI: 10.1371/ journal.pone.0104679.

Gogala A. 2004. First record of Andrena chrysopus Perez in Slovenia (Hymenoptera: Andrenidae). Acta Entomologica Slovenica 12 (1): 168.

Hedicke H. 1933. Beiträge zur Systematic der Gattung Andrena F. (Hym. Apid.). Mitteilungen aus dem Zoologischen Museum in Berlin 19: 199-220.

HOLZER K. A. 2014. Amphibian use of constructed and remnant wetlands in an urban landscape. Urban Ecosystems 17: 955-968. DOI: 10.1007/s11252-014-0373-0

Hostetler M. E. \& MCintyre N. E. 2001. Effects of urban land use on pollinator (Hymenoptera: Apoidea) communities in a desert metropolis. Basic and Applied Ecology 2: 209-218. DOI: 10.1078/1439-1791-00051

HuAN-Li X. \& TADAuChi O. 2012. A Revision of the Subgenus Euandrena of the Genus Andrena of Eastern Asia (Hymenoptera: Apoidea: Andrenidae). Esakia 52: 77-90. DOI: 10.11646/zootaxa.2145.1.2

KOWARIK I., KÖRNER S. (eds), 2005. Wild urban woodlands. New perspectives for urban forestry. Springer, Berlin, Heidelberg.

KrAuss J., ALFERT T. \& STEFFAN-DEWENTER I. 2009. Habitat area but not habitat age determines wild bee richness in limestone quarries. Journal of Applied Ecology 46: 194-201 DOI: 10.1111/j.1365-2664.2008.01582.x

LERMAN S. B. \& MilAM J. 2016. Bee fauna and floral abundance within lawn dominated suburban yards in Springfield, MA. Annals of the Entomological Society of America 109: 713-723. DOI: 10.1093/aesa/saw043

Levchenko T. V. 2010. Fauna and ecology of bees (Hymenoptera: Apoidea), Moscow Region. Ph. D. thesis. Mosk. state un-t them. Mv Lomonosov, Ill. RSL OD, 61 10-3/639, 356 pp.

LEVChEnKo T. V., YuFEREV G. I. 2015. Zoogeographical analysis of the bee's fauna (Hymenoptera: Apoidea: Apiformes) in the Kirov region. Eurasian Symposium on Hymenoptera Insects, N. Novgorod, 103-104.

Lundholm J. T., Richardson P. J. 2010. Habitat analogues for reconciliation ecology in urban and industrial environments. Journal of Applied Ecology 47: 966-975. DOI: 0.1111/j.1365-2664.2010.01857.x

MAtUSZKIEWICZ W. 2006. Przewodnik do oznaczania zbiorowisk roślinnych Polski. Warszawa: Wyd. Naukowe PWN. (in Polish)

MCKINNEY M. L. 2002. Urbanization, Biodiversity, and Conservation: The impacts of urbanization on native species are poorly studied, but educating a highly urbanized human population about these impacts can greatly improve species conservation in all ecosystems. Bioscience 52: 883-890. DOI: 10.1641/00063568(2002)052[0883:UBAC]2.0.CO;2

MCKINNEY M. L. 2008. Effects of urbanization on species richness: A review of plants and animals. Urban Ecosystems 11 (2): 161-176. DOI: $10.1007 / \mathrm{s} 11252-007-0045-4$

Menke S. B., Guenard B., Sexton J. O., Weiser M. D., Dunn R. R. \& Silverman J. 2011. Urban areas may serve as habitat and corridors for dry-adapted, heat tolerant species; an example from ants. Urban Ecosystems 14: 135163. DOI: 10.1007/s11252-010-0150-7

OSYTSHnJUK A. 1977. Apoidea. Family Andrenidae. Kyiv, Naukowa Dumka, 328 s. (Fauna Ukraine; Volume 12, Issue 5). [In Ukrainian]

RADCHENKO W. 1980. O stroenii gnezda i trofičeskih svâzâh Andrena chrysopus (Hymenoptera, Andrenidae). Vestnik zoologii 3: 88-90. [ In Ukrainian].

Rasmont P., Roberts S. P. M., Michez D., Schweiger O., Franzen M., De Meulemeester T., Tomozei B. \& RADCHENKO V. 2013. Atlas of the European Bees: genus Andrena. 1st Edition. STEP Project, Atlas Hymenoptera, Mons, Gembloux. http:/WWW.atlashymenoptera.net/page.asp?ID=243.

RUTKOWSKi L. 2004. Klucz do oznaczania roślin naczyniowych Polski Niżowej. Wydawnictwo Naukowe PWN, Warszawa. [In Polish]

Shochat E., Lerman S. B., Anderies J. M., Warren P. S., FAeth S. H. \& Nilon C.H. 2010. Invasion, competition, and biodiversity loss in urban ecosystems. BioScience 60( 3): 199-208. DOI: 10.1525/bio.2010.60.3.6

TWERD L., BANASZAK-CIBICKA W. 2019. Wastelands: their attractiveness and importance for preserving the diversity of wild bees in urban areas. Journal of Insect Conservation 23 (3): 573-588. DOI: 10.1007/s10841-019-00148-8 
Twerd L., Banaszak-Cibicka W., Sobieraj-Betlińska A., Waldon-Rudzionek B., Hoffmann R. 2021a. Contributions of phenological groups of wild bees as an indicator of food availability in urban wastelands. Ecological Indicators 126: 107616. DOI: 10.1016/j.ecolind.2021.107616

Twerd L., Sobieraj-Betlińska A., SzEFER P. 2021b. Roads, railways, and power lines: Are they crucial for bees in urban woodlands? Urban Forestry \& Urban Greening 61:127120. DOI: 10.1016/j.ufug.2021.127120

\section{STRESZCZENIE}

[Pierwsze stwierdzenia Andrena chrysopus Perez, 1903 (Hymenoptera: Apiformes: Andrenidae) w Polsce]

Pierwsze informacje o występowaniu Andrena chrysopus Perez, 1903 w Polsce pochodzą z Bydgoszczy (Nizina Wielkopolsko-Kujawska). Gatunek odłowiony został na roślinie pokarmowej Asparagus officinalis L. na obrzeżach miasta oraz w dzielnicach mieszkaniowoprzemysłowych. W sezonach 2018-2019 (maj-czerwiec) został odnotowany na dziewięciu stanowiskach w łącznej liczbie 54 osobników. 